\title{
Design of a Prototype Wastewater Treatment Plant for Selected Households
}

\author{
Eunice D. Macpepple ${ }^{1 *}$, Celestine C. Egwuonwu ${ }^{1}$, Francis N. Orji ${ }^{2}$, Stephena E. Tolubanwo ${ }^{3}$ \\ ${ }^{1}$ Department of Agricultural and Bioresources Engineering, Federal University of Technology, Owerri, Nigeria. \\ ${ }^{2}$ Department of Agricultural and Bioresources Engineering, Michael Okpara University of Agriculture, \\ Umudike, Nigeria. \\ ${ }^{3}$ National Root Crop Research Institute, Umudike, Nigeria.
}

*Corresponding Author: Eunice D. Macpepple, Department of Agricultural and Bioresources Engineering, Federal University of Technology, Owerri, Nigeria.

\begin{abstract}
Domestic wastewater comprising of raw sewage and sullage is predominately emptied directly into open water bodies and surrounding soils in Port-Harcourt city and its coastal communities. This practice exists as a result of the absence of functional sustainable wastewater treatment plants in the area. To address this problem, a prototype waste treatment plant was designed for selected households in Opobo town, Rivers State, Nigeria. The treatment units designed comprise of a sump and pump house unit, an approach channel, a screen chamber, and a primary and biological treatment unit. The aeration and settling tanks have a tank volume of $11.1 \mathrm{~m} 3$ and $13.45 \mathrm{~m} 3$ respectively; with an estimated BOD removal of $60-70 \%$ and $20-30 \%$ suspended solids.
\end{abstract}

Keywords: Wastewater; Collection system; Raw sewage; Riverine communities; Opobo Town; gravity sewer.

\section{INTRODUCTION}

Around the globe, solid and liquid waste are naturally generated anywhere humans are found. The higher the population of an area, the more quantity of waste generated. Sewage in most parts of Nigeria is usually collected in septic tanks from residential houses, institutions, recreational and commercial areas, left there until the tanks are full, and then evacuated by the government environmental authorities. In Rivers State there is only one known sewage treatment plant in Eagle Island, Port-Harcourt, which is scarcely adequate to serve the municipality alone. Due to this incapacity, a lot of sewage collection vehicles dispose of the collected raw sewage directly into rivers, gutters and other surface waters in and around the city. Some residents who cannot afford to pay the collection vehicles simply evacuate their filled septic tanks directly into surrounding soils. This situation is even worse in towns and villages situated in the coastal areas of Rivers State, where raw sewage is directly dumped into the receiving waters on a daily basis.

The disposal of these feacal and organic matter directly into surface waters, soils and the surrounding environment produces offensive odours, negatively affects human health, causes aquatic life to suffer and negates the aesthetics of an environment.

According to [1] "untreated wastewater results in high intensity ascariasis infections comprised of cognitive impairment, severe dysentery and anemia". Other diseases related to this activity are "schistosomiasis, trachoma, trichuriasis, hookworm disease, malaria, yellow fever, filariasis, dengue, hepatitis A and E, typhoid, arsenicosis, fluorosis and legionellosis". Skin diseases, salmonellosis, shigellosis, gastric ulcers, giardiasis and amoebiasis are also diseases that result from the presence of feaces and body wastes in surface waters.

"Eutrophication is another negative outcome of this poor sanitation practice. Nutrients contained in human excreta produce phosphorus and nitrogen in the river. This increases the nutrients and result in algal blooms, loss of oxygen, fish kills and loss of biodiversity, amongst other problems" [1].

To address this poor practice of waste disposal, waste treatment plants are required in coastal areas and in densely populated peri-urban and urban areas of Rivers State and other parts of Nigeria, where 
domestic and industrial wastewater can be treated effectively to produce effluent that is safe when discharged into receiving waters, whether inland or coastal; and also to produce effluent that can be reused for agriculture or aquaculture [2].

[3] designed a waste treatment plant for the city of Contorro, Cuba, for the reduction and eventual stoppage of contaminating the Vento aquifer from raw sewage. Their process design involved a range of unit processes and their removal efficiencies. [4] designed a waste treatment plant for the Malali housing estate, Kaduna, Nigeria, where a waste stabilization pond was found to be more economical than polluting the surrounding environment. Other developing countries where waste treatment plants have been successfully implemented in municipalities and peri-urban areas according to [5] are in Nicaragua, Columbia, Sri Lanka, Karachi, Malang, Pakistan, Indonesia, etc.

\subsection{Study Area}

The selected households used for this research are situated in Opobo Town, a peri-urban settlement in the Niger Delta area of Rivers State, Nigeria. According to [1], Opobo is located at the southern part of Nigeria just beneath Ikot Abasi, Akwa Ibom State. It lies between latitude $4^{\circ} 30^{\prime} 41.11^{\prime \prime} \mathrm{N}$ and longitude $7^{\circ} 32^{\prime} 24.32$ " E. The town is inclusive in the total area of $130 \mathrm{~km}^{2}$ of the local government area, and has an average elevation of $4 \mathrm{~m}$ above sea level. Opobo town is bounded on the south by the Atlantic Ocean, on the north by Khana, east by Ikot Abasi and west by Andoni (figure 1).

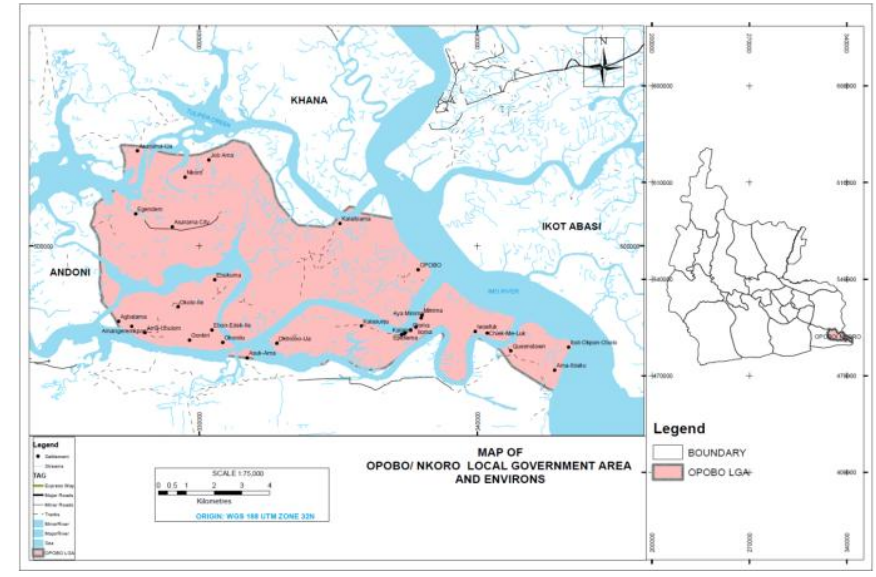

Figure 1. Map of Opobo Town

Source. (MacPepple et al., 2017)

\section{Materials AND Methods}

\subsection{Materials}

a) Questionnaires

b) Interviews

c) Maps

\subsection{Methodology}

The methodology employed for this study included survey and mapping of the study area, interview and questionnaire survey and the wastewater treatment units design. Questionnaires were distributed to the residents living within the study area, to ascertain how much water they consume and generate daily. Onsite survey work was also carried out which involved reconnaissance, establishment of points, traversing, detailing and leveling of the study area.

According to [6] a wastewater treatment plant is mainly comprised of the preliminary treatment units (sump or holding tank and pump unit, approach channel, screen chamber, grit chamber and skimming tank), the primary treatment unit, the secondary treatment unit and the tertiary unit. The selection of treatment units by a designer is dependent on the properties of the waste to be treated and the desired final effluent. Taking the study area of a cluster of about 30 households in Opobo town, prototype design of a wastewater treatment system comprised of a sump and pump house, an approach channel, bar screen chamber, primary sedimentation tank and a secondary clarifier before final effluent. Using the data derived from the questionnaire survey analysis, the base population is 540 persons. Since 
there is no available census data for the study area, assumed values were used to estimate the number of persons for five decades earlier (table 1).

Table1. Decade increase rate in population

\begin{tabular}{|l|l|l|}
\hline Year & Population & Increase (x) \\
\hline 1975 & 120 & \\
\hline 1985 & 210 & 90 \\
\hline 1995 & 338 & 125 \\
\hline 2005 & 428 & 90 \\
\hline 2015 & 540 & 112 \\
\hline Total & 417 \\
Average & & 104.25 \\
\hline
\end{tabular}

\subsubsection{Population Projection}

Projected population is given by the relation.

$P_{n}=P_{o}+n c$

Where,

$P_{n}=$ population at $n$ year

$P_{o}=$ population at the base year

$n=$ number of years (in decades)

Using the arithmetic increase method, the base population $\mathrm{P}_{0}$ for year 2015 is

$P_{0}=540$

The projected population for the year 2030 is:

$P_{1}=540+(1.5 \times 104.25)=696$

So projected population for the year 2045 will be:

$P_{2}=540+(3 \times 104.25)=853$ persons in study area

\subsubsection{Treatment Unit Sizing}

a. Computation of the Average Daily Wastewater Flow Rat

The average daily flow of wastewater per capita, $Q_{a v g}$ (from questionnaire survey results) $=79 \mathrm{l} / \mathrm{d}$

Total daily wastewater flow of study area, $Q_{\text {avg }}=79 l / d x 853$ residents

$\mathrm{Q}_{\mathrm{avg}}=67,387 \mathrm{l} / \mathrm{d}$

$\mathrm{Q}_{\mathrm{avg}}=\frac{67387}{10^{6}} \mathrm{MLD}=0.067387 \mathrm{MLD}$

$Q_{\text {avg }}=0.067387 \times 10^{3} \mathrm{~m}^{3} / \mathrm{d}$

$\mathrm{Q}_{\text {avg }}=67.387 \mathrm{~m}^{3} / \mathrm{d}$

b. Capacity or Volume of the Unit for Average Daily Flow

Volume of treatment unit, $V_{\text {avg }}=\left(Q_{\text {avg }} \times t\right) / 24$

Where,

$V_{\text {avg }}=$ volume of a tank or realtor, $m^{3}$

$Q_{\text {avg }}=$ average daily flow rate, $\mathrm{m}^{3} / d$

$t=$ hydraulic detention time, $d$

With a detention time of say 2 hrs, and using the formula for tank capacity as:

$$
\begin{aligned}
V_{\text {avg }}=67.387\left(\frac{m^{3}}{d}\right) \times 2(h) & \times \frac{1}{24}\left(\frac{h}{d}\right) \\
V_{\text {avg }} & =5.62 \mathrm{~m}^{3}
\end{aligned}
$$

\section{c. Calculation of Maximum and Minimum Flows}

To calculate maximum or peak flow $\left(Q_{\max }\right)$ a peaking factor of 2.5 is used in the equation:

$Q_{\max }=P F_{\max } \times Q_{\text {avg }}$

Where,

$Q_{\max }=$ maximum flow rate

$P F_{\text {max }}=$ maximum peaking factor

$Q_{\text {avg }}=$ average flow rate 
$Q_{\max }=2.5 \times 67.387=168 \mathrm{~m}^{3} / \mathrm{d}$

Minimum peak flow can be calculated using the assumed number of 1.5 as the peaking factor:

$Q_{\text {min }}=P F_{\min } \times Q_{\text {avg }}$

Where,

$Q_{\min }=$ minimum flow rate

$P F_{\text {min }}=$ minimum peaking factor

$Q_{\text {avg }}=$ average flow rate

$$
Q_{\min }=1.5 \times 67.387=101 \mathrm{~m}^{3} / \mathrm{d}
$$

d. The volume of tank for maximum flow conditions:

$V_{\max }=\left(Q_{\max } \times t\right) / 24$

$V_{\max }=168\left(\frac{m^{3}}{d}\right) \times 2(h) \times \frac{1}{24}\left(\frac{h}{d}\right)$

The maximum velocity $V_{\max }$ is

$V_{\max }=8.8$

\subsection{Wastewater Treatment Plant Design}

A) Design of Sump and Pump Wells

i) Calculation of maximum and minimum sewage flow:

$Q_{\text {avg }}=0.067 M L D=0.067 M L D \times 1000 \mathrm{~m}^{3} / \mathrm{d}$

Maximum sewage flow reaching the pumping station,

$$
Q_{\max }=\text { Peaking factor } x Q_{\text {avg }}
$$

Assuming the minimum flow as $30 \%$ of the average flow,

$$
\begin{gathered}
Q_{\min }=0.3 \times 67.387 \mathrm{~m}^{3} / d \\
Q_{\max }=2.5 \times 67.387 \frac{\mathrm{m}^{3}}{\mathrm{~d}} \\
=\frac{2.5 \times 67.387}{24 \times 60 \times 60} \mathrm{~m}^{3} / \mathrm{s} \\
Q_{\max }=0.0019 \mathrm{~m}^{3} / \mathrm{s}
\end{gathered}
$$

Minimum sewage flow $Q_{\min }$ is:

$$
\begin{gathered}
Q_{\min }=\frac{20.216}{24 \times 60 \times 60} \mathrm{~m}^{3} / \mathrm{s} \\
=2.33 \times 10^{-4} \mathrm{~m}^{3} / \mathrm{s}
\end{gathered}
$$

ii) Design of rising main:

Assuming $0.75 \mathrm{~m} / \mathrm{s}$ as the flow through velocity in the rising main, the cross sectional area of the rising main, $A_{x}$ at peak flow will be:

$A_{x}=\frac{\text { flow }\left(Q_{\max }\right)}{\text { velocity }}$

$$
A_{x}=\frac{0.0019 \mathrm{~m}^{3} / \mathrm{s}}{0.75 \mathrm{~m} / \mathrm{s}}=0.0026 \mathrm{~m}^{2}
$$

The diameter of the rising main, $\mathrm{d}_{\mathrm{R}}$ is determined by the equation,

$$
d_{R}=\sqrt{\frac{4 \times A_{x}}{\pi}}
$$




$$
d_{R}=\sqrt{\frac{4 \times 0.0026}{\pi}}
$$

$d_{R}=0.06 m$

So a rising main of $60 \mathrm{~mm}$ will be provided.

iii) Design of the sump well (wet well):

Assuming that the sump well retains the flow of wastewater for 20 minutes, the maximum quantity of sewage in the sump $Q_{s}$ is:

$Q_{s}=Q_{\max } \times t$

$=0.0019\left(\mathrm{~m}^{3} / \mathrm{s}\right) \times 20 \times 60(\mathrm{~s})$

$=2.28 \mathrm{~m}^{3}$

The quantity of sewage in the rising main $R_{S}$ of $20 \mathrm{~m}$ length (assumed) is

$R_{s}=\frac{\pi}{4} \times d_{R} \times d_{T}$

Where,

$R_{S}=$ Quantity of sewage in rising main

$d_{R}=$ rising main diameter

$d_{T}=$ distance from sump to treatment unit

$\therefore R_{s}=\frac{\pi}{4} \times(0.06)^{2} \times 20=0.06 \mathrm{~m}^{3}$

The total capacity of the sump required, $\mathrm{T}_{\mathrm{c}}$ is:

$T_{C}=$ quantity of sewage in the sump

+ quantity of sewage in the rising main

$T c=2.28 m^{3}+0.06 m^{3}$

$T c=2.34 \mathrm{~m}^{3}$

The minimum liquid depth in the sump well $L_{d}$ is:

$L_{d}=Q_{\text {min }}$ in the well + flow in the rising main

Therefore, the minimum liquid depth in each well $L_{d}$ is given by:

$L_{d}=\frac{\text { volume }}{\text { surface area }}$

Assuming a maximum of $2.0 \mathrm{~m}$ depth of the sump, the surface area $A_{s}$ of the sump is given by:

$A_{s}=\frac{T_{c}}{2}$

$=\frac{2.34}{2}=1.17 \mathrm{~m}^{2}$

Providing 2 sump wells for 2 pumps, 1 working and 1 standby $(1 \mathrm{~W}+1 \mathrm{~S})$ such that 1 well will always remain in operation in case of repair/maintenance, the surface area of one sump $A_{s 1}$ is:

$$
\begin{aligned}
\frac{A_{s}}{2} & =\frac{1.17}{2} \\
\therefore A_{s 1} & =0.585 \mathrm{~m}^{2}
\end{aligned}
$$

So the minimum liquid depth $L_{d}$ in the sump well is

$=\frac{0.34 \mathrm{~m}^{3}}{0.59 \mathrm{~m}^{2}}=0.6 \mathrm{~m}$

The diameter of each sump $d_{s}$ is: 
$d_{s}=\sqrt{\frac{4 \times 0.59}{\pi}}$

Now as the diameter of each sump is $0.87 \mathrm{~m}$, the area of one wet well will be

$$
\frac{\pi}{4} \times(0.87)^{2}=0.59 \mathrm{~m}^{2}
$$

The minimum volume of liquid in the well is:

$=\left[0.00023\left(\frac{m^{3}}{s}\right) \times 20 \times 60(s)\right]+0.06\left(\mathrm{~m}^{3}\right)$ (Assuming 20 min detention

$$
=0.34 \mathrm{~m}^{3}
$$

iv) Design of pump:

The maximum flow that the pump has to lift is,

$$
Q_{\text {pump }} \text { or } Q_{\max }=\frac{0.0019 \mathrm{~m}^{3}}{\mathrm{~s}}
$$

Computing frictional losses in pipe,

$h_{f}=\frac{f L v^{2}}{2 \times g \times d}$

Where,

$h_{f}=$ head loss due to friction, $m$

$f=$ coefficient of friction (0.01, assumed)

$L=$ length of the pipe, $m$

$v=$ velocity of flow in the pipe (rising main), $\mathrm{m} / \mathrm{s}$

$g=$ gravitational acceleration, $m / s 2$

$d=$ diameter of the pipe (rising main), $m$

$h_{f}=\frac{0.01 \times 20(\mathrm{~m}) \times\left[0.75\left(\frac{\mathrm{m}}{\mathrm{s}}\right)\right]^{2}}{2 \times 9.81\left(\mathrm{~m} / \mathrm{s}^{2}\right) \times 0.06(\mathrm{~m})}=0.13 \mathrm{~m}$

Assuming losses in bends to be $0.5 \mathrm{~m}$,

Total lift head of sewage, $H=$ pumping head + losses in head

$$
H=9.5+0.13+0.5=10.13 m
$$

Computing the power required, $\mathrm{P}$, the following equation is used:

$P=\frac{w \times Q_{p} \times H}{75 \times \eta_{\mathrm{p}} \times \eta_{\mathrm{m}}}$

Where,

$w=$ density of water, $\mathrm{kg} / \mathrm{m}^{3}=1000 \mathrm{~kg} / \mathrm{m}^{3}$

$Q_{p}=$ flow to be lifted by pump, $\mathrm{m}^{3} / \mathrm{s}=0.0019 \mathrm{~m}^{3} / \mathrm{s}$

$H=$ total head (total lift of sewage), $m=10.13 \mathrm{~m}$

$\eta_{p}=$ efficiency of pump $=65 \%$ (assumed)

$$
\eta_{m}=\text { efficiency of the driving motor }=75 \% \text { (assumed) }
$$

$$
\begin{aligned}
\therefore \text { Required Power, } P= & \frac{1000\left(\frac{\mathrm{kg}}{\mathrm{m}^{3}}\right) \times 0.0019\left(\mathrm{~m}^{3} / \mathrm{s}\right) \times 10.13(\mathrm{~m})}{75 \times 0.65 \times 0.75}(B H P) \\
& =0.526 \mathrm{BHP}=0.3922 \mathrm{~kW}
\end{aligned}
$$

So if one well requires $0.526 \mathrm{BHP}$, the total power required for two wells will be $1.05 \mathrm{BHP}(0.78 \mathrm{~kW})$. 
v) Design of the suction pipe:

The maximum flow in the pipe for the well is $0.0019 \mathrm{~m}^{3} / \mathrm{s}$.

Assuming the velocity of flow in pipe, $\mathrm{v}$ is $=1.0 \mathrm{~m} / \mathrm{s}$, the cross sectional area of the intake pipe,

$$
A_{x}=\frac{0.0019}{1.0}=0.0019 \mathrm{~m}^{2}
$$

Therefore the diameter, $\mathrm{d}_{\mathrm{in}}$, of the suction or inlet pipe is

$$
\begin{gathered}
d_{\text {in }}=\sqrt{\frac{4 \times 0.0019}{\pi}} \\
d_{\text {in }}=0.05 \mathrm{~m} \\
d_{\text {in }}=50 \mathrm{~mm}
\end{gathered}
$$

vi) Design of Approach Channel:

For a maximum wastewater flow of $168 \mathrm{~m}^{3} / \mathrm{d}$,

$Q_{\max }=\frac{168}{24 \times 60 \times 60} \mathrm{~m}^{3} / \mathrm{s}=0.0019 \mathrm{~m}^{3} / \mathrm{s}$

Computing channel dimensions,

Flow through velocity $\left(\mathrm{V}_{\mathrm{h}}\right)$ is assumed to be $0.75 \mathrm{~m} / \mathrm{s}$ in the channel, the required cross sectional area of the channel will be:

$A_{x}=\frac{Q_{\max }}{V_{h}}$,

$A_{x}=\frac{0.0019}{0.75} \mathrm{~m}^{2}=0.0025 \mathrm{~m}^{2}$

Assuming width to depth ratio, $B: D=1.5: 1$

$$
\begin{gathered}
B=1.5 \mathrm{D} \\
A_{x}=1.5 \mathrm{D} \times \mathrm{D} \\
0.0025=1.5 \mathrm{D}^{2} \\
D=0.04 \mathrm{~m} \\
\text { And } B=1.5 \times 0.04=0.06 \mathrm{~m}
\end{gathered}
$$

Therefore net cross sectional area, (Breadth $\mathrm{x}$ Depth) is

$$
0.06 \times 0.04=0.0024 \mathrm{~m}^{2}
$$

Assuming freeboard of $0.03 \mathrm{~m}$, the total depth of the tank is

$$
D=0.04+0.03=0.07 m
$$

Assuming length of channel as $0.5 \mathrm{~m}$, the channel design is a $0.5 \mathrm{~m}$ long channel of $60 \mathrm{~mm}(0.06 \mathrm{~m})$ width and $70 \mathrm{~mm}(0.07 \mathrm{~m})$ total depth.

Checking for flow through velocity, $\mathrm{V}_{\mathrm{h}}$, using Manning's formula,

$$
V_{h=\frac{1}{n} R^{2 / 3} S^{1 / 2}}
$$

Where,

$n=0.013$ (for cement concrete in good condition),

Wetted perimeter $P$, of the channel is

$2 D+B$

$P=(2 \times 0.04+0.06)=0.14 m$ 
The hydraulic mean radius is

$R=A / P=0.0024 /(0.14)=0.017 \mathrm{~m}$

Assuming slope of channel, $S=1: 1000$,

$$
\begin{gathered}
V_{h}=\frac{1.0 \times 0.017^{2 / 3} \times 0.001^{1 / 2}}{0.013} \\
=0.16 \mathrm{~m} / \mathrm{s}
\end{gathered}
$$

vii) Design of Screen Chamber:

For a maximum flow of $0.0019 \mathrm{~m} 3 / \mathrm{s}$ of the domestic wastewater in each channel (from the designed approach channel), and using the same dimensions of the approach channel for the screen chamber,

We have $\mathrm{L}=0.5 \mathrm{~m}, \mathrm{~B}=0.06 \mathrm{~m}$ and $\mathrm{D}=0.04 \mathrm{~m}$

Therefore, the cross sectional area,

$$
A_{x}=B \times D=0.06 \times 0.04=0.0024 m^{2}
$$

Computing approach (flow through) velocity, $V_{h}$,

$$
\begin{gathered}
V_{h}=\frac{Q_{\max }}{\text { Area }} \\
V_{h}=\frac{0.0019}{0.0024} \\
V_{h}=0.79 \mathrm{~m} / \mathrm{s}
\end{gathered}
$$

\section{Computing the number of bars}

Using bars of $10 \mathrm{~mm} \times 50 \mathrm{~mm}$ with a clear opening of $10 \mathrm{~mm}$, let $\mathrm{n}$ be the number of bars, then

Width of opening $(n+1)+$ width of bars $(n)=B$ (total width)

$0.01(n+1)+0.01(n)=B(\text { total width })^{`}$

$0.01(n+1)+0.01(n)=0.06 m$

$n=3$

Hence 3 bars of $10 \mathrm{~mm} \times 50 \mathrm{~mm}$ with $10 \mathrm{~mm}$ clear spacing will be provided.

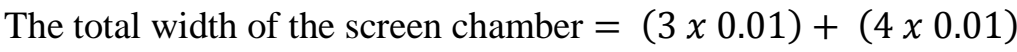

$$
=0.07 \mathrm{~m}
$$

So 3 bars are adjusted in a total width of $7 \mathrm{~cm}$.

\section{Calculating flow velocity through the screen bars $v$}

The effective width of channel, during flow through the screen, $B_{e}$ is:

$B_{e}=$ total width - width of 3 bars

Then the velocity of flow through the screen bars, $v$, is,

$v=\frac{\text { flow }}{\text { cross sectional area }}$

$B_{e}=0.07-(0.01 \times n)$

$B_{e}=0.07-(0.01 \times 3)=0.04 \mathrm{~m}$

And wastewater depth $\mathrm{D}$ is $0.04 \mathrm{~m}$,

Therefore the effective cross sectional area of the screen is

$$
B_{e} \times D=0.04(m) \times 0.04(m)=0.0016 m^{2}
$$


Then the velocity of flow through the screen bars, $\mathrm{v}$, is

$v=\frac{0.0019 \mathrm{~m}^{3} / \mathrm{s}}{0.0016 \mathrm{~m}^{2}}=1.2 \mathrm{~m} / \mathrm{s}$

Calculating head loss through the bar rack,

$h_{l}=0.0729\left(v^{2}-v_{h}{ }^{2}\right)$

Where,

$v_{h}=$ velocity before the screen $=0.88 \mathrm{~m} / \mathrm{s}$

$v=$ velocity through the screen $=1.6 \mathrm{~m} / \mathrm{s}$

$h_{l}=0.0729\left[(1.2)^{2}-(0.79)^{2}\right] \quad$ from equation $(3.23)$

$=0.06 \mathrm{~m}$

(This is acceptable as headloss since it is less than the design criteria, $0.15 \mathrm{~m}$ )

\section{Calculating the quantity of screening}

Assuming the screening production of $0.0015 \mathrm{~m} 3 / \mathrm{ML}$ of flow, for $10 \mathrm{~mm}$ opening and a flow of 0.106 MLD,

$$
\begin{gathered}
\text { Quantity of screening produced }=0.0015\left(\mathrm{~m}^{3} / M L\right) \times 0.168(M L D) \\
=0.000252 \frac{\mathrm{m}^{3}}{d}=0.3 \frac{\text { litres }}{d}
\end{gathered}
$$

\section{Design of perforated plate}

Provide the length of the plate equal to the width of the chamber, which is $0.06 \mathrm{~m}$.

Assuming the width of the plate is 0.03 and depth of the pocket is equal to $0.02 \mathrm{~m}$ for collecting screenings, the capacity of the screening pocket,

$$
C_{s}=0.06 \times 0.03 \times 0.02=3.6 \times 10^{-5} \mathrm{~m}^{3}
$$

\section{Computing the inclined length of bars,}

$L_{b}=\frac{\operatorname{Dept} h, D}{\sin 45^{\circ}}$

$=(0.07) /\left(\sin 45^{\circ}\right)=0.10 \mathrm{~m}$

So bars of total length $0.1 \mathrm{~m}$ will be provided.

\section{Finally calculating the length of the screen chamber,}

Horizontal projected length is $0.1 \times \cos 45^{\circ}=0.07 \mathrm{~m}$

Let the length of the outlet zone be the length of the perforated plate $+0.02 \mathrm{~m}$ (assumed).

Assuming the length of the inlet zone as $0.08 \mathrm{~m}$, the total length of the screen chamber is

$$
0.08+0.07+0.05=0.2 m
$$

\section{B) Design of Primary Sedimentation Tank}

i) Computing the average daily and peak flows in each tank

$$
Q_{\text {avg }}=\frac{67.387 \mathrm{~m}^{3} / \mathrm{d}}{2}=33.69 \mathrm{~m}^{3} / \mathrm{d}
$$

Assuming peaking factor of 2.5 , peak flow for each tank is,

$$
\begin{gathered}
Q_{\text {peak }}(\text { in each tank })=\text { peaking factor } x Q_{\text {avg }} \\
=2.5 \times 33.69 \mathrm{~m}^{3} / \mathrm{d}
\end{gathered}
$$




$$
=84.23 \frac{m^{3}}{d}
$$

ii) Computing the surface area of each tank,

$$
S L R=\frac{\text { flow }}{\text { surface area }}=\frac{Q}{A_{S}}
$$

The surface area of each tank at $Q_{\text {avg }}$ is given by

Surface area of unit, $A_{s}=\frac{\text { flowrate, } m 3 / d}{\text { surface loading rate, } \frac{m 3}{m 2} / d}$

$$
A_{s 1}=\frac{Q}{S L R}=\frac{33.69 \mathrm{~m}^{3} / d}{40}
$$

$\therefore$ For average flow conditions, $A_{s 1}=0.84 \mathrm{~m}^{2}$

iii) Computing the diameter of the tank, $d_{1}$

$$
\begin{array}{r}
d_{1}=\sqrt{\frac{A_{s} \times 4}{\pi}} \\
d_{1}=\sqrt{\frac{0.84 \times 4}{\pi}} \\
=1.03 \mathrm{~m}
\end{array}
$$

iv) Computing the volume of tank, $\mathrm{V}$,

$V=Q_{\text {avg }} \times t \quad$ (Where, $\mathrm{t}$ is the detention time in days)

$V=67.387\left(\frac{m^{3}}{d}\right) \times\left(\frac{2}{24}\right)(d)$

$V_{1}=5.62 \mathrm{~m}^{3}$

$$
\therefore \text { Volume of each tank }=\frac{5.62}{2}=2.81 \mathrm{~m}^{3}
$$

v) Computing the side water depth (effective liquid depth) in the tank,

The SWD in each tank is given by,

$D_{1}=\frac{V(\text { volume of the tank })}{A_{s}(\text { surface area of the tank })}$

$D_{1}=\frac{2.81 \mathrm{~m}^{3}}{0.84 \mathrm{~m}^{2}} D_{1}=3.35 \mathrm{~m}$

The liquid depth or side water depth (SWD) is within the recommended range of 3 to $5 \mathrm{~m}$, so design is acceptable.

vi) Design of the hopper bottom:

Calculation of sludge production.

The volume of sludge produced each day in each tank is calculated by the equation,

$\mathrm{V}_{\mathrm{sl}}=\frac{\mathrm{M}_{\mathrm{sl}}}{\rho_{\mathrm{w}} \times \mathrm{s}_{\mathrm{sl}} \times \mathrm{P}_{\mathrm{s}}}$

Where,

$\mathrm{V}_{\mathrm{sl}}=$ volume of sludge, $\frac{\mathrm{m}^{3}}{\mathrm{~d}}$

$\mathrm{M}_{\mathrm{sl}}=$ mass of sludge, $\mathrm{kg} / \mathrm{d}$ 


$$
\begin{aligned}
& \rho_{\mathrm{w}}=\text { density of water, } \frac{\mathrm{kg}}{\mathrm{m}^{3}}\left(998.20 \text { at } 20^{\circ} \mathrm{C}\right) \\
& \mathrm{s}_{\mathrm{sl}}=\text { specific gravity of primary sludge }=1.03 \text { (assumed) } \\
& \quad \mathrm{P}_{\mathrm{S}}=\text { percentage solids in primary sludge expressed as decimals }=0.06 \text { (assumed) }
\end{aligned}
$$

To determine the mass of primary sludge generated,

$\mathrm{M}_{\mathrm{sl}}=60 \%$ of suspended solids in the influent

$$
\begin{aligned}
& =0.60 \times 250\left(\frac{\mathrm{mg}}{\mathrm{L}}\right) \times 33.69\left(\frac{\mathrm{m}^{3}}{\mathrm{~d}}\right) \times 10^{3}\left(\frac{\mathrm{L}}{\mathrm{m}^{3}}\right) \\
& =5054 \times \frac{10^{3} \mathrm{mg}}{\mathrm{d}}=5.1 \mathrm{~kg} / \mathrm{d}=0.21 \mathrm{~kg} / \mathrm{h}
\end{aligned}
$$

Computing the volume of primary sludge produced,

$$
\begin{aligned}
& \mathrm{V}_{\mathrm{sl}}=\frac{5.1 \mathrm{~kg} / \mathrm{d}}{998.2\left(\frac{\mathrm{kg}}{\mathrm{m}^{3}}\right) \times 1.03 \times 0.06}, \\
& =0.08 \mathrm{~m}^{3} / \mathrm{d} \\
& =0.0034 \mathrm{~m}^{3} / \mathrm{h}
\end{aligned}
$$

Computing hopper bottom capacity:

Capacity of sludge pocket, $\mathrm{C}=\mathrm{V}_{\mathrm{sl}} \times \mathrm{t}$

$\mathrm{C}=0.0034\left(\frac{\mathrm{m}^{3}}{\mathrm{~h}}\right) \times 4(\mathrm{~h})$,

$=0.014 \mathrm{~m}^{3}$

Assuming $\mathrm{A}=0.3 \mathrm{~m}, \mathrm{~B}=0.4 \mathrm{~m}$ and $\mathrm{H}=0.13 \mathrm{~m}$ for the trapezoidal section of the hopper bottom, the volume of hopper bottom is given by the equation,

$$
V=\frac{1}{3} H\left(B^{2}+A B+A^{2}\right)
$$

$\mathrm{V}=\frac{1}{3} 0.13\left[0.4^{2}+(0.3 \times 0.4)+0.3^{2}\right]$

$=0.016 \mathrm{~m}^{3}$

As this value is greater than the computed capacity of $0.014 \mathrm{~m}^{3}$, providing a hopper bottom of $0.016 \mathrm{~m}^{3}$ is acceptable.

vii) Computing the overall depth of the tank

Total depth of the tank $=$ liquid depth + freeboard + depth for tank bottom slope + hopper bottom depth

Assuming $10 \%$ slope to bottom of the tank for sludge scrapping, the depth for bottom slope is.

$\mathrm{S}_{1}=\left(\frac{\mathrm{d}}{2}-\frac{\mathrm{B}}{2}\right) \times 0.10$

$\mathrm{S}_{1}=\left(\frac{1.03}{2}-\frac{0.4}{2}\right) \times 0.10$

$=0.032 \mathrm{~m}$

So the total depth of tank $\mathrm{D}_{1}=3.35+0.03+0.032+0.13$

$$
\therefore \mathrm{D}_{1}=3.54 \mathrm{~m}
$$

viii) Computing the diameter of the central feed pipe 


$$
\begin{aligned}
& A_{x}=\frac{\text { flow }}{\text { velocity }} \\
& A_{x}=\frac{33.69 \mathrm{~m}^{3} / \mathrm{d}}{0.9\left(\frac{\mathrm{m}}{\mathrm{s}}\right) \times 60\left(\frac{\mathrm{min}}{\mathrm{n}}\right) \times 60\left(\frac{\mathrm{s}}{\mathrm{min}}\right) \times 24\left(\frac{\mathrm{h}}{\mathrm{d}}\right)} \\
& =4.3 \times 10^{-4} \mathrm{~m}^{\mathrm{s}}
\end{aligned}
$$

$\therefore$ The diameter of feed pipe, $d_{p}=\sqrt{\frac{4 \times A_{x}}{\pi}}$

$\mathrm{d}_{\mathrm{p}}=\sqrt{\frac{4 \times 4.3 \times 10^{-4}}{\pi}}=0.023 \mathrm{~m}=23 \mathrm{~mm}$

So a central feed pipe of $23 \mathrm{~mm}$ will be provided.

C) Design of Secondary Treatment Units

i) Computing the concentration of soluble BOD5 $\left(\mathrm{S}_{\text {sol }}\right)$ in the effluent

The total effluent BOD5 is given by the relation:

$\mathrm{S}_{\text {total }}=\mathrm{S}_{\mathrm{sol}}+\mathrm{S}_{\mathrm{ss}}$

$\mathrm{S}_{\text {total }}$ is $30 \mathrm{mg} / \mathrm{L}$ (desired) and Sss is determined by the relation:

$\mathrm{S}_{\mathrm{ss}}=68 \%$ of ultimate BOD due to suspended solids

$=0.68[1.42 \times$ (biodegradable fraction of suspended effluent biomass) $]$

$=0.68 \times(1.42 \times 65 \%$ of $25 \mathrm{mg} / \mathrm{L})$

$=15.70 \mathrm{mg} / \mathrm{L}$

Note: 1.42 is conversion factor to determine oxygen demand for ultimate BOD of biomass

Therefore,

$$
\begin{aligned}
\mathrm{S}_{\text {sol }} & =30-15.70 \mathrm{mg} / \mathrm{L} \\
& =14.30 \mathrm{mg} / \mathrm{L}
\end{aligned}
$$

So we have,

$$
\begin{gathered}
\text { Concentration of soluble } \mathrm{BOD}_{5} \text { in the effluent, } \mathrm{S}_{\mathrm{sol}}=14.30 \mathrm{mg} / \mathrm{L} \\
\text { Concentration of suspended } \mathrm{BOD}_{5} \text { in the effluent, } \mathrm{S}_{\mathrm{ss}}=15.70 \mathrm{mg} / \mathrm{L} \\
\text { Concentration of total effluent } \mathrm{BOD}_{5}, \quad \mathrm{~S}_{\text {total }}=30 \mathrm{mg} / \mathrm{L}
\end{gathered}
$$

ii) Computing treatment efficiency, $\mathrm{E}$

Based on soluble $\mathrm{BOD}_{5}$,

$$
\begin{aligned}
& E_{\text {sol }}=\frac{s_{0}-S_{\text {sol }}}{s_{0}} \times 100 \\
& E_{\text {sol }}=\frac{200-14.30}{200} \times 100 \\
& =92.85 \%
\end{aligned}
$$

Based on total effluent $\mathrm{BOD}_{5}$,

$\mathrm{E}_{\text {total }}=\frac{200-30}{200}$

$=85.0 \%$

iii) Computing the reactor volume, $\mathrm{V}$

Volume of the reactor is given by the relation, 


$$
\mathrm{V}=\frac{\mathrm{Q}_{\mathrm{avg}} \times \mathrm{Y} \times \theta_{\mathrm{c}} \times\left(\mathrm{S}_{0}-\mathrm{S}_{\mathrm{sol}}\right)}{\mathrm{X} \times\left(1+\mathrm{K}_{\mathrm{d}} \theta_{\mathrm{c}}\right)}
$$

$\mathrm{V}=\frac{0.067 \times 10^{3}\left(\frac{\mathrm{m}^{3}}{\mathrm{~d}}\right) \times 0.5 \times 10(\mathrm{~d}) \times\left[200-14.30\left(\frac{\mathrm{mg}}{\mathrm{L}}\right)\right]}{3500\left(\frac{\mathrm{mg}}{\mathrm{L}}\right) \times\left[1+\left(0.06\left(10^{-1}\right) \times 10(\mathrm{~d})\right]\right.}$,

$\mathrm{V}=11.1 \mathrm{~m}^{3}$

iv) Computing the hydraulic retention time (HRT), $\theta$

HRT, $\theta=\frac{\mathrm{V}}{\mathrm{Q}}$

Where,

$\mathrm{V}=$ volume of reactor

$\mathrm{Q}=$ wastewater quantity $=\mathrm{Q}_{\mathrm{avg}}$

HRT, $\theta=\frac{11.1 \mathrm{~m}^{3}}{0.067 \times 10^{3}\left(\frac{\mathrm{m}^{3}}{\mathrm{~d}}\right)}$

$=0.17 \mathrm{~h}$

So volume of reactor based on HRT, V $=67 \mathrm{~m}^{3} / \mathrm{d} \times \frac{0.17}{24}(\mathrm{~d})$

$$
=0.475 \mathrm{~m}^{3}
$$

This shows that the volume of reactor is adequate since based on HRT the calculated volume is larger.

v) Computing sludge wasting rate

Case 1: Sludge wasting from recycled line, $Q$ 'w is computed from the relation,

$\theta_{c}=\frac{V \times X}{\left(Q_{w}^{\prime} \times X_{r}\right)+\left(Q_{e} \times X_{e}\right)}$

Where,

$\mathrm{V}=$ volume of reactor $=11.1 \mathrm{~m}^{3}$

$\mathrm{X}=$ MLVSS in the reactor $=3,500 \mathrm{mg} / \mathrm{L}$

$\mathrm{Q}_{\mathrm{w}}^{\prime}=$ sludge wasting rate (flow)

$\mathrm{X}_{\mathrm{r}}=$ concentration of recycled sludge $=10,000 \mathrm{mg}$ of MLSS $/ \mathrm{L}$

$\mathrm{X}_{\mathrm{e}}=$ Effluent biomass concentration (assumed to be neglected)

$\theta_{\mathrm{c}}=$ Mean cell residence time $=10 \mathrm{~d}$

$$
\begin{gathered}
\mathrm{Q}_{\mathrm{w}}^{\prime}=\frac{\mathrm{V} \times \mathrm{X}}{\theta_{\mathrm{c}} \times \mathrm{X}_{\mathrm{r}}} \\
\mathrm{Q}_{\mathrm{w}}^{\prime}=\frac{11.1\left(\mathrm{~m}^{3}\right) \times 3,500(\mathrm{mg} / \mathrm{L})}{10(\mathrm{~d}) \times(0.8 \times 10,000)\left(\mathrm{mg} \frac{\mathrm{MLSS}}{\mathrm{L}}\right)} \\
\mathrm{Q}_{\mathrm{w}}^{\prime}=4.9 \mathrm{~m}^{3} / \mathrm{d}
\end{gathered}
$$

Case 2: Sludge wasting from the reactor, $Q_{W}$ is calculated by

$$
\theta_{c}=\frac{\mathrm{V} \times \mathrm{X}}{\left(\mathrm{Q}_{\mathrm{w}} \times \mathrm{X}\right)+\left(\mathrm{Q}_{\mathrm{e}} \times \mathrm{X}_{\mathrm{e}}\right)}
$$

Where,

$\mathrm{V}=$ volume of reactor $=11.1 \mathrm{~m}^{3}$

$\mathrm{X}=$ MLVSS in the reactor $=3,500 \mathrm{mg} / \mathrm{L}$ 
$\mathrm{Q}_{\mathrm{w}}=$ sludge wasting rate from the reactor

$\mathrm{X}_{\mathrm{e}}=$ Effluent biomass concentration $=0$ (assumed to be neglected)

$\theta_{\mathrm{c}}=$ Mean cell residence time $=10 \mathrm{~d}$

$$
\begin{gathered}
\theta_{\mathrm{c}}=\frac{\mathrm{V} \times \mathrm{X}}{\left(\mathrm{Q}_{\mathrm{w}} \times \mathrm{X}\right)} \\
\mathrm{Q}_{\mathrm{w}}=\frac{\mathrm{V}}{\theta_{\mathrm{c}}}=\frac{11.1\left(\mathrm{~m}^{3}\right)}{10(\mathrm{~d})}, \\
=1.11 \mathrm{~m}^{3} / \mathrm{d}
\end{gathered}
$$

vi) Computing the oxygen required for aeration,

$$
\begin{aligned}
& \text { BOD }_{\mathrm{L}}=\frac{\mathrm{Q}_{\mathrm{avg}} \times\left(\mathrm{S}_{0}-\mathrm{S}_{\mathrm{sol}}\right)}{0.68} \\
& \mathrm{BOD}_{\mathrm{L}}=\frac{67 \frac{\mathrm{m}^{3}}{\mathrm{~d}}}{0.68} \times\left(\frac{200-14.30}{10^{3}}\right)\left(\mathrm{kg} / \mathrm{m}^{3}\right), \\
& =18.30 \mathrm{~kg} / \mathrm{d}
\end{aligned}
$$

Now the oxygen per day can be calculated using,

$\mathrm{O}_{2}$ required per day $=($ mass of BODL utilized $)-1.42 \times$ (mass of biomass waste $)$

$$
=18.30-1.42 \times 3.9=12.76 \frac{\mathrm{kg}}{\mathrm{d}}=0.5 \mathrm{~kg} / \mathrm{h}
$$

D) Design of Secondary sedimentation tank

i) Computing the surface area of the tank,

Assuming overflow loading rate, OFR is $15 \mathrm{~m} / \mathrm{d}$,

The surface area of the tank, $A_{s}$ is

$A_{s}=\frac{Q}{O F R}$

$A_{s}=\frac{67 \mathrm{~m}^{3} / \mathrm{d}}{15 \mathrm{~m} / \mathrm{d}}=4.5 \mathrm{~m}^{2}$,

Tank diameter, $\mathrm{d}$ is given by:

$d=\sqrt{\frac{4 \times A_{s}}{\pi}}$

$d=\sqrt{\frac{4 \times 4.5}{\pi}}$

$=2.4 \mathrm{~m}$

ii) Computing the total volume of the tank, assuming SWD to be $3 \mathrm{~m}$, the effective volume of tank V, is

$V=A_{S} x D$

$V=4.5\left(\mathrm{~m}^{2}\right) \times 3(\mathrm{~m})=13.6 \mathrm{~m}^{3}$

Providing freeboard of $0.03 \mathrm{~m}$, the total depth of the tank will be

$$
D_{\text {total }}=3+0.03=3.03 \mathrm{~m}
$$

And the total volume of the tank 


$$
V_{\text {total }}=4.5\left(\mathrm{~m}^{2}\right) \times 3.03(\mathrm{~m})=13.64 \mathrm{~m}^{3}
$$

iii) Computing hydraulic retention time $\theta$,

$$
\begin{aligned}
& \theta=\frac{\text { effective volume of tank }}{\text { flow of wastewater }\left(Q_{\text {peak }}\right)} \\
& \begin{aligned}
\theta=\frac{13.6 \mathrm{~m}^{3}}{168.47 \mathrm{~m}^{3} / \mathrm{d}} \\
=0.08 \mathrm{~d} \\
=1.92 \mathrm{~h}
\end{aligned}
\end{aligned}
$$

\section{RESULTS AND DISCUSSION}

\subsection{Results}

Table2. Design Summary of Sump and Pump House

\begin{tabular}{|l|l|l|}
\hline S/No. & Design parameter & Value \\
\hline 1 & Number of wet well sumps & 2 \\
2 & Number of dry wells & 1 \\
3 & Diameter of a rising main & $60 \mathrm{~mm}$ \\
4 & Diameter of wet wells & $0.87 \mathrm{~m}$ \\
5 & Maximum liquid depth in a wet well & $2.0 \mathrm{~m}$ \\
6 & Minimum liquid depth in a wet well & $0.6 \mathrm{~m}$ \\
7 & Total head for pumping & $10.13 \mathrm{~m}$ \\
8 & Diameter of an intake pipe & $50 \mathrm{~mm}$ \\
9 & Number of pumps & $2(1 \mathrm{~W}+1 \mathrm{~S})$ \\
10 & Total power for pumping & $0.756 \mathrm{BHP}(0.56 \mathrm{KW})$ \\
\hline
\end{tabular}

Table3. Design Summary of Approach Channel

\begin{tabular}{|l|l|l|}
\hline S/No. & Design parameter & Value \\
\hline 1 & Type of channel & Rectangular \\
2 & Number of units & 1 (with 2 channels) \\
3 & Length of the channel, L & $0.5 \mathrm{~m}$ \\
4 & Width of the channel, B & $0.06 \mathrm{~m}$ \\
5 & Net depth of flow, D & $0.04 \mathrm{~m}$ \\
6 & Depth including free board & $0.07 \mathrm{~m}$ \\
7 & Free board & $0.03 \mathrm{~mm}$ \\
8 & Slope of channel & $1: 1000$ \\
\hline
\end{tabular}

Table4. Design Summary of Screen Chamber

\begin{tabular}{|l|l|l|}
\hline S/No. & Design parameter & Value \\
\hline 1 & Number of units & 1 (with 2 channels) \\
2 & Length of chamber, L & $0.2 \mathrm{~m}$ \\
3 & Width of chamber, B & $0.06 \mathrm{~m}$ \\
4 & Depth of chamber, D & $0.07 \mathrm{~m}$ (with free board) \\
5 & Size of bars & $10 \mathrm{~mm} \times 50 \mathrm{~mm}$ \\
6 & Clear opening between bars & $10 \mathrm{~mm}$ \\
7 & Inclination of bars & $45^{\circ}$ \\
8 & Size of perforated plate & $0.06 \mathrm{~m} \times 0.03 \mathrm{~m}$ \\
9 & Screening collection pocket & $0.06 \mathrm{~m} \times 0.03 \mathrm{~m} \times 0.02 \mathrm{~m}$ \\
\hline
\end{tabular}

Table5. Design Summary of Primary Sedimentation Tank

\begin{tabular}{|l|l|l|}
\hline S/No & Design parameter & Value \\
\hline 1 & Number of units & 2 \\
2 & Volume of each tank & $2.81 \mathrm{~m}^{2}$ \\
3 & Diameter of each tank, $\mathrm{d}_{1}$ & $1.03 \mathrm{~m}$ \\
4 & Effective liquid depth in each tank (SWD), $\mathrm{D}_{1}$ & $3.35 \mathrm{~m}$ \\
5 & Freeboard, FB & $0.03 \mathrm{~m}$ \\
6 & Total depth of each tank, $\mathrm{D}_{1}$ & $3.54 \mathrm{~m}$ \\
7 & Diameter of central feed influent pipe, $\mathrm{d}_{\mathrm{p}}$ & $23 \mathrm{~mm}$ \\
8 & Diameter of sludge removal pipe & 8 \\
\hline
\end{tabular}


Table6. Design Summary for Secondary Treatment Unit

\begin{tabular}{|c|c|c|}
\hline S/No & Design parameter & Value \\
\hline a) & Aeration tank & \\
\hline 1 & Volume of the tank or reactor, $\mathrm{V}$ & $11.1 \mathrm{~m}^{3}$ \\
\hline 2 & Sludge wasting rate - for recycle line & $4.9 \mathrm{~m}^{3} / \mathrm{d}$ \\
\hline 3 & Sludge wasting rate - for reactor & $1.11 \mathrm{~m}^{3} / \mathrm{d}$ \\
\hline 3 & Oxygen required & $0.5 \mathrm{~kg} / \mathrm{h}$ \\
\hline b) & Secondary settling tank & \\
\hline 1 & Number of tanks & 1 \\
\hline 2 & Effective volume of tank, $\mathrm{V}$ & $13.6 \mathrm{~m} 3$ \\
\hline 3 & Total volume of tank, $\mathrm{V}_{\text {total }}$ & $13.64 \mathrm{~m}^{3}$ \\
\hline 4 & Tank diameter & $2.4 \mathrm{~m}$ \\
\hline 5 & Effective liquid depth in the tank (SWD), $\mathrm{D}_{1}$ & $3 \mathrm{~m}$ \\
\hline 6 & Freeboard, FB & $0.03 \mathrm{~m}$ \\
\hline 7 & Total depth of tank, $\mathrm{D}_{1}$ & $3.3 \mathrm{~m}$ \\
\hline 8 & Hydraulic retention time, HRT & $1.92 \mathrm{~h}$ \\
\hline
\end{tabular}
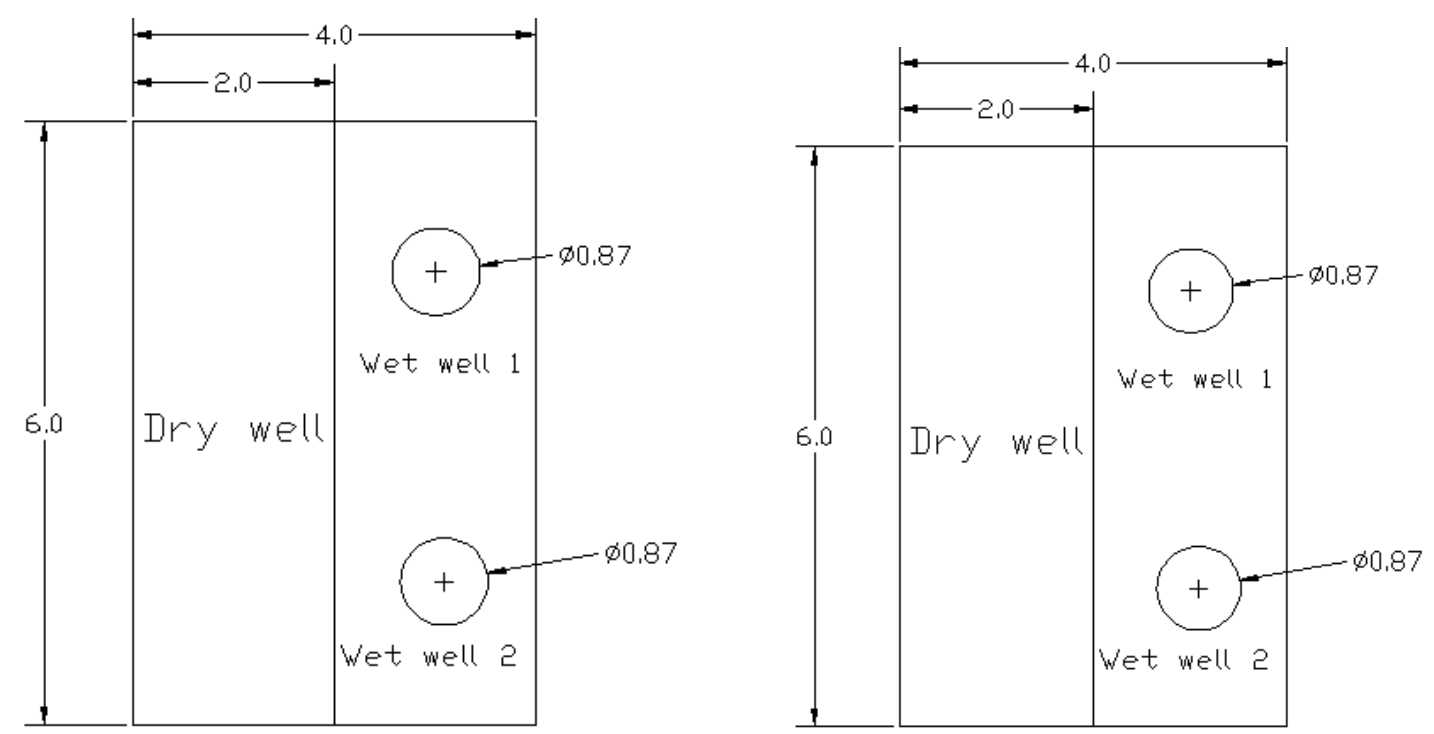

Figure 2. Sump and pump house
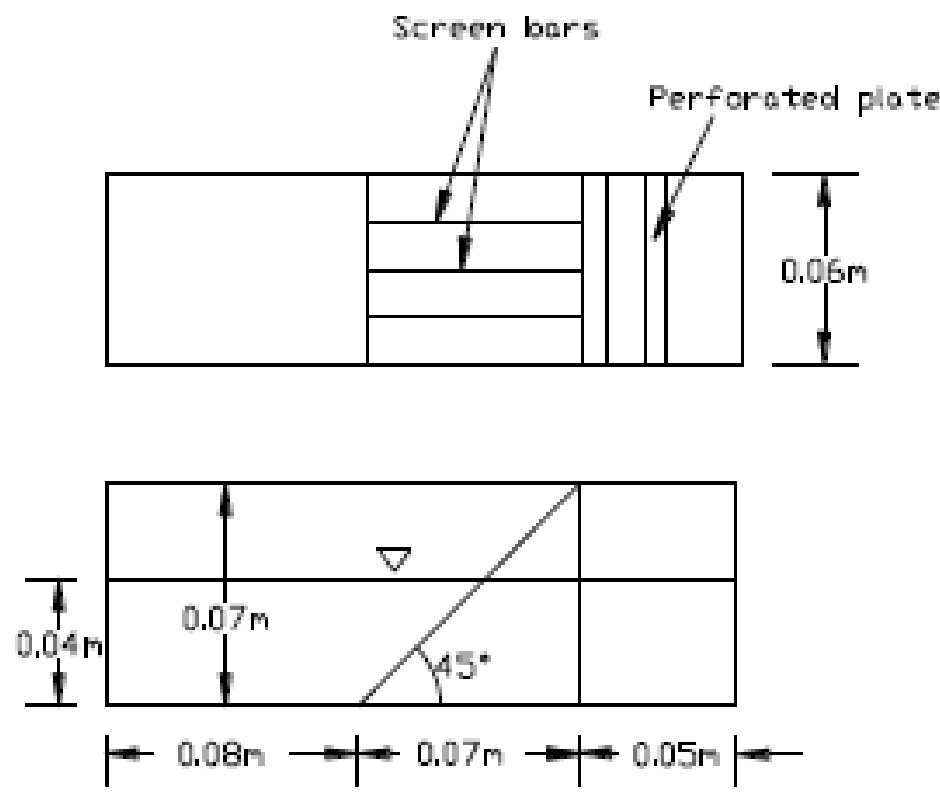

Figure 3. Bar screen details 


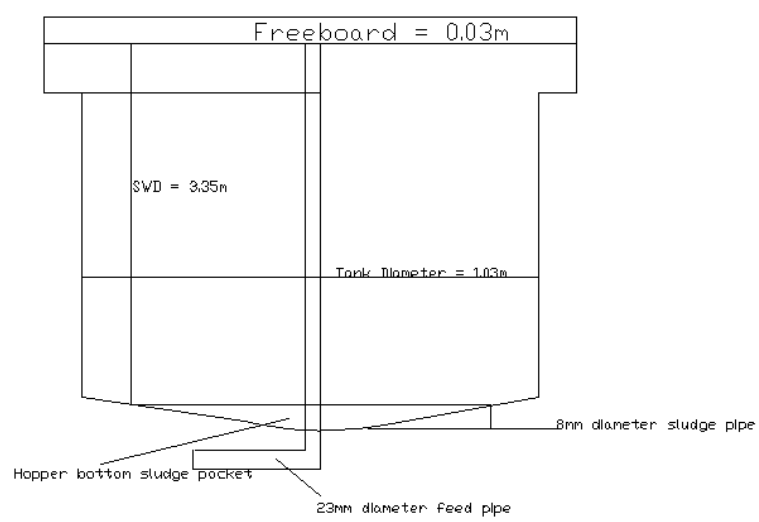

Figure 4. Primary sedimentation tank

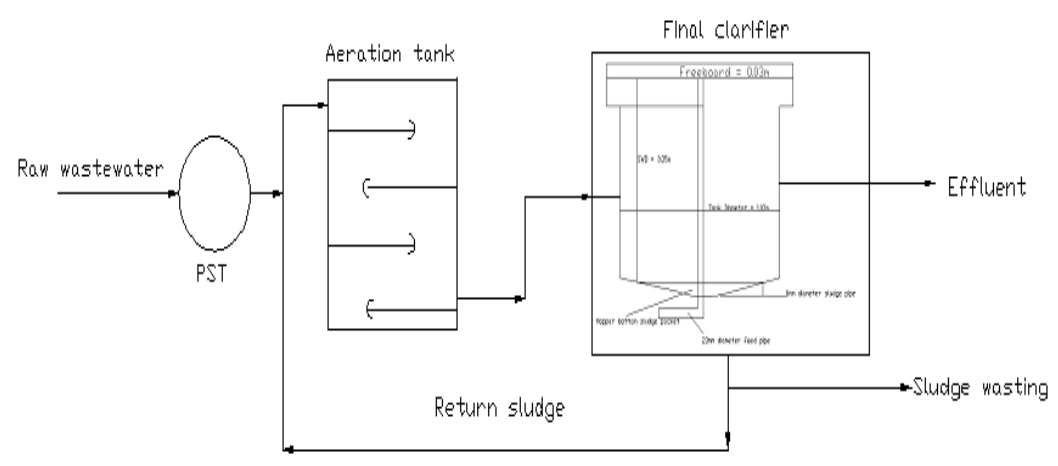

Figure 5. Biological treatment units

\subsection{Discussion}

The results of the interview survey established that the system was to be designed for a total of 540 persons with average water consumption and usage of approximately1,419 litres/day/household and a total baseflow of 42,578 litres of wastewater per day. Figure 4.6 show the schematic layout of the designed treatment plant. A total of 540 persons will be served by the plant and by a population projection analysis 853 residents in 30 years. The wastewater from the selected households flows by gravity to a sump unit or holding tank (also called a wet well), having a total liquid depth of $2.0 \mathrm{~m}$. A centrifugal pump then pumps the wastewater to an approach channel of dimension $0.5 \mathrm{~m} \mathrm{x} 0.06 \mathrm{~m} \mathrm{x}$ $0.04 \mathrm{~m}$ which reduces the turbulence of the pumped wastewater to a steadier and uniform flow. From this point the wastewater flows into the screen chamber of dimension $0.2 \mathrm{~m} \times 0.06 \mathrm{~m} \times 0.07 \mathrm{~m}$. Here floating materials and coarse solids are removed from the wastewater. Next the wastewater flows into the primary sedimentation tank of depth $3.54 \mathrm{~m}$ where a large portion of mainly inorganic suspended materials are settled out of the influent. An estimated $60-70 \%$ suspended solids and $20-30 \%$ associated BOD is removed. The wastewater finally proceeds to the secondary treatment units comprising of an aeration tank with a total tank volume of $11.1 \mathrm{~m} 3$ and a final settling tank of volume $13.64 \mathrm{~m} 3$; here colloidal and dissolved solids from the primary effluent is removed. This gives a final effluent of not more than $50 \mathrm{mg} / \mathrm{l}$ suspended solids and about $20 \mathrm{mg} / \mathrm{l}$ soluble BOD5. At this stage, the wastewater is safer to be discharged into the surrounding waters.

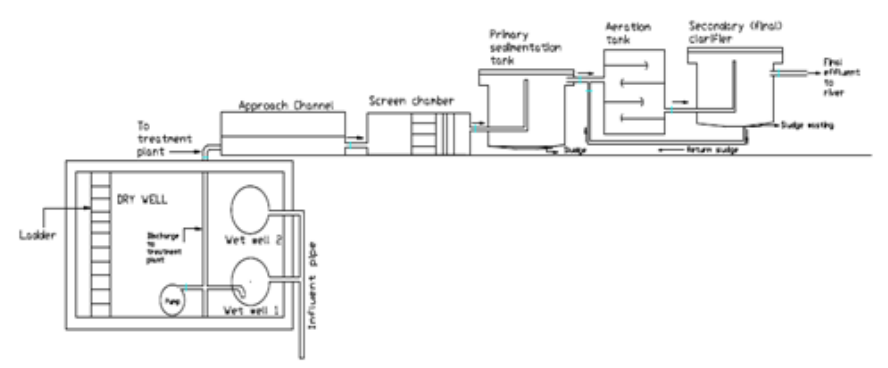

Figure 6. Treatment plant layout 


\section{CONCLUSION}

This research has clearly demonstrated the feasibility of designing a wastewater treatment plant for domestic and industrial treatment of wastewater in a peri-urban area. To save human and aquatic life, it will be proper to undertake a comprehensive review of the management of waste in the study area as well as other parts of the country and the Rivers State Government and other state governments in Nigeria should consider wastewater treatment as a top priority for the total wellness of the ecosystem.

\section{REFERENCES}

[1] MacPepple, E., Okereke, N., Egwuonwu, C., \& Igoni, A. H. (2017). Effect of Raw Sewage on Surface Water Quality in Opobo Town, Nigeria.

[2] Mara, D. and Horan, N. J. (Eds), (2003). Handbook of Water and Wastewater

[3] Microbiology. Academic press. 441-449.

[4] Ortega-Castineiras, C., Kajder, K., \& Ramoutar, R. (2009). Conceptual Design of a Wastewater Treatment Plant for the Municipality of Cotorro, Province of Havana, Cuba. Cuba in Transition, 19.

[5] Akali, D. M., Adie, D. B., and Iorhemen, O. T. (2012). Comparative Analysis on the Use of Septic Tank and Sanitary Sewerage Systems at Malali Housing Estate, Kaduna-Nigeria. International Journal of Engineering Research and Technology, 1(9): 1-2.

[6] Mara, D. D., Sleigh, A., and Tayler, K. (2001). PC-based Simplified Sewer Design. University of Leeds: $1-89$.

[7] Karia, G. L., and Christian, R. A. (2013). Wastewater Treatment: Concepts and Design Approach. PHI Learning Pvt. Ltd.

Citation: Eunice D. Macpepple, et.al,"Design of a Prototype Wastewater Treatment Plant for Selected Households", International Journal of Research in Environmental Science (IJRES), vol. 5, no. 3, pp. 65-82, 2019. Available: DOI: http://dx.doi.org/10.20431/2454-9444.0503008

Copyright: (C) 2019 Authors. This is an open-access article distributed under the terms of the Creative Commons Attribution License, which permits unrestricted use, distribution, and reproduction in any medium, provided the original author and source are credited. 